\title{
Personal Integrity of Islamic Counselor on Professional Ethics Commitment
}

\author{
Asti Haryati \\ Institut Agama Islam Negeri Bengkulu, Indonesia \\ astiharyati91@gmail.com
}

Article Information:

Received January 10, 2018

Revised January 17, 2018

Accepted January 26, 2018

\section{Keywords:}

Islamic Counselor, Commitment, Professional Ethics.

\begin{abstract}
A system, method, technique, or scientific competence will not be efficient as long as it is not done by a counselor who has a personal quality and integrity. Ethics, behaviors and good personality which appropriate to Islamic Sharia values should be improved to make a qualified Islamic counselor. An Islamic counselor with integrity means an honest person with a strong character, including consistency in all actions. A counselor who has integrity toward commitment will be able to show a good performance on duties and accordance with the authority within the value and professional ethics. In this article, author will attempt to describe what is personal of counselor that can support the effectiveness of the guidance and counseling services, the professional ethics of counselor that provided by the guidance and counseling profession organization, and personal integrity that can be seen from the words and actions that counselor do in the daily life.
\end{abstract}

\section{INTRODUCTION}

A research that provided the survey data of the general population, counselors and counselor educators indicate that spiritual and religious issues are therapeutically relevant, ethically appropriate and potentially significant topics in counseling and counselor education (Hanin Hamjah \& Mat Akhir, 2014). It is should be considered by the party who involved in developing guidance and counseling as a new paradigm or islamization of science, eventhough, dilemmas and opportunities are raised in attempts to formulate an Islamic guidance and counselling paradigm (Abdullah, 2009).

Islamic counseling basically giving assistance toward clients to achieve and implement a balance in life. Islamic counseling is a "helping" activity, it is said to be helping because, in essence, it is the counselee self who needs to live according to God's guidance (the straight path) for their own prosperity (Sutoyo, 2013). In other word, the implemetation of guidance and counseling should based on islamic values in conjunction with the al Qur'an and Hadith from Muhammad (Peace Be Upon Him - PBUH) (Inayat, 2001). Because the position of the counselor is helping, and the consequences of the individual himself must actively learn to understand and simultaneously implement the guidance of Islam.

The personality of counselor can determine the form of relationship between counselor and counselee, the form of problem-solving quality and the decision of alternative problem solving (Munir, 2010). Thus, the counselor is someone who has the ability to provide counseling services based on professional standards. Recognizing the professionalism of Islamic counselor cannot be separated on the recognizing academic qualifications, fulfillment of performance standards, and compliance requirements professionalism and concerning the values of Islamic morality.

How to cite :

E-ISSN:

Published by: Available online:
Haryati, A. (2018). Personal Integrity of Islamic Counselor on Professional Ethics Commitment. Islamic Guidance and Counseling Journal, 1(1), 11-16. https://doi.org/10.25217/igci.v1i1.191 2614-1566

Institut Agama Islam Ma'arif NU (IAIMNU) Metro Lampung https://journal.iaimnumetrolampung.ac.id/index.php/igcj 
Islamic counselor assumed as a person who will guide the counselee to achieve certain goals, then in this relationship is needed the integrity of professional ethical commitment that must be owned by Islamic counselor. Ethical issue, integrity is considered as honesty and truth which is the accuracy of one's actions. Thus, Islamic counselor must have the integrity of professional ethics which in essence will encourage the formation of a person who could resist the temptation and all forms of intervention, by promoting the demands of conscience to uphold truth and justice, and always trying to do his duty according to the professional ethics of Islamic counselor to achieve counseling goals.

In addition, it is important to considering cultural competence and sensitivity within the multicultural society especialy in muslim clients (Graham, Bradshaw, \& Trew, 2009). The appropriate way for islamic counselor is to incorporate islamic values and ethical in professional counseling. Social religiosity and spirituality is very strongly correlated with personal religiosity and spirituality (Zayed, 2017). Thus, a counselor should consider how to interact appropriately with the environment and the society.

This paper will describe issues are which related to the personal integrity of Islamic counselors to their commitment to professional ethics. The discussion will begin with a personal of Islamic counselor, it will be continued with professional ethics, and ended with the problem of how to develop it in everyday life.

\section{DISCUSSION}

\section{Personal of Islamic Counselor}

From the perspective of Islamic guidance and counseling is within the realm of da'wah and communication, it is about how the counselor acts as a preacher who delivers a message to his counselee in order to make counselee have certain attitudes and behaviors. Islamic counselor needs to pay attention to factors that can support the success of the service. The persona of the counselor is a supporting success among the factors. It is the foundation of Islamic counselor shaping the competence of the counseling.

Islamic counselor should have a good personality. The quality of the counselor is all the criteria of excellence, including personal, knowledge, insight, skills, and values that will facilitate him in carrying out the counseling process to achieve the goal successfully and effectively (Wilis, 2007). Quality of behaviors are needed to become a counselor, the list bellow aspects of counselor personal life, 1) Curiosity and concern, 2) Listening ability, 3) Loving to talk, 4) Empathy and understanding, 5) Hold back emotions, 6) Introspection, 7) Capacity of self-denial, 8) Tolerance of intimacy, 9) Abling to rule, 10) Able to laugh, 11) Intellectual competence, 12) Energy, 13) Flexibility, 14) Supporting, 15) Goodwill, and 16) Self-awareness (Gladding, 2012). Therefore, individuals who decided to be involved in counselor profession must be able to adapt all forms of counselor personality above in order to achieve effective self-qualities.

Some research of counseling experts have found that the effectiveness of counselors is largely determined by the quality of personality. In general, according to the results of the research, especially in Indonesian context, some characteristics of personality that counselor needs to possess are as follows, 1) Faithful and cautious, 2) Loving people, 3) Skilled in communicators, 4) Good listener, 5) Having a wide range of knowledge, especially about human insight and socio-cultural, 6) Becoming a competent resource person, 7) Flexible, calm, and patient, 8) Mastering skills and techniques, 9) Having intuition, 10) Understand the professional ethics, 11) Respect, honest, genuine, respectful, and unappreciative, 12) Empathy, understanding, accepting, warm, and friendly; 13) Facilitators and motivators, 14) Stable emotions, clear mind, quick, and capable, 15) Objective, rationale, logical, and concrete, and 16) Consistent and responsible (Wilis, 2007). The counselor who does not have 
skill in communication often labelled the counselee, consequences of this act is very dangerous to the sustainable of the counseling sevices (Kushendar \& Maba, 2017)

While the personal criteria of this Islamic counselor are 1) The Islamic counselor should be the person who controls the material especially in the matter of Islamic religious knowledge, so that his knowledge is sufficiently relating to religious matters, 2) An Islamic counselor should be a person who practices Islamic values well and consistently, reflected through faith, piety, and religious practice in daily life, 3) an Islamic counselor as much as possible is able to transfer the rules of Islamic values broadly relevant to problem of the counselee, 4) an Islamic counselor should master the right methods and strategies, 5) Islamic counselors have good personalities as role models in behavior, 6) Islamic counselors should master the field of psychology in an integral manner (Munir, 2010).

Meanwhile, the Association of Indonesian Guidance and Counseling Professions (ABKIN) formulated that one of the components the standard of competence that must be imbued and owned by the counselor is to develop personally and professionally sustainable, which includes, 1) Believer and fear to God the Almighty, 2) Showing integrity and stability of a strong personality, 3) Having self-awareness and commitment to professional ethics, 4) Implementing collaboration at the internal job and externally between profession, and 5) Taking a part in the professional organization and activities in guidance and counseling (ABKIN, 2007).

Thus, from what is expressed by the experts above, hinted that an Islamic counselor should have effective personal qualities from the side of Islamic sharia and moral values of counseling and able to be a good examples for the counselee. It shows that the counselor's personal qualities to be a determinant factor for the attainment of counseling in addition to knowledge about behavioral dynamics and therapeutic skills in counseling. The counselor must be continuously trying to develop and control himself. He must understand the shortcomings and prejudices to themselves, which may affect its relationship with others and result in low quality of professional services as well as harm the counselee (Hidayah, Elia, Boli, \& Hambali, 2017).

The counselor capable to show commendable attitudes and emphasizing in counseling sessions, as following, 1) repentance, 2) patience, 3) gratitude, 4) trust in God, 5) acceptance, 6) meditation, 7) reflection, and 8) remembering death (Hanin Hamjah \& Mat Akhir, 2014). The counselor able to see the mistakes that has been made in the past then try to avoid the same mistakes in the future, through unconvenient times but able to passed without complaining, always thankful, surrender to God for whatever happened, consenting to receive everything the unwanted, focus on mind to achieve clear mentally and emotionally, casting back to valued what have been done, and remember the life in the world is temporarily.

Despite already having a professional code of ethics that the reference for counselee protection, for Islamic counselors there is nothing wrong if in itself also add the characteristics of the counselor who perceived necessary for the activities of counseling to improve the quality of persona and the competency of the counseling.

\section{Professional Ethics in Counseling}

From the perspective of etymology (origin of the word), the term ethics comes from the Latin word "ethicus" and in Greek is called "ethicos" meaning habit (Rismawaty, 2008). Ethics in Islam is as an instrument of infinite and great value that not only contains the attitude, the normative behavior, that is in the form of human relationship with God (faith), but the manifestation of human relationship to God, Man and the universe from the perspective of historicity (Mudlor, 1993).

In the Indonesian code of ethics counseling profession, the foundations are 1) pancasila, considering that counseling profession as a service for humanity in order to educating the responsible citizen, and 2) profession demands, considering the needs and wellbeing of the 
counselee regarding the norms (Wiyono, 2003). Therefore, the counselor should possesed the insight, knowledge, skills, values and attutudes which has been mentioned above.

The basic principle of ethics which is part of a grant that serves to improve the ethics of counselor toward a professional level. these basic principles are described as follows (Ishak, Amat, \& Bakar, 2012); 1) Autonomy, this principle shows the freedom of a counselee to choose their own direction, 2) Non- malfeasance, a professional counselor should strive to avoid harm counselee of a counseling process, whether physical, emotional, and psychological, or a potential client's offensive behavior, 3) Beneficence, this principle explains that through the counseling process is able to produce a better condition for the counselee, 4) Justice, this justice means that every counseling process undertaken to each counselee must be the same, regardless of any factor, 5) Fidelity, fidelity means that a professional counselor must give a true promise and not give a false promise that it must be committed to those they serve.

Applying all these fifth principles to achieve the professionalism of a counselor is not an easy work, especially to counselees from multiple cultures. Professional ethics of counselor which becomes behavioral rules to be the reference for the counselor in carrying out his duties and responsibilities in providing guidance and counseling services for counselees.

\section{Personal Integrity of Counselors on Professional Ethics Commitment}

Integrity is a complex concept with alliances to conventional standards of moralityespecially those of truth telling, honesty, and fairness-as well as to personal ideals that may conflict with such standards (McFall, 1987). In other words, Integrity is the principle of being principled, practicing what one preaches regardless emotional or social pressure, and not allowing any irrational consideration to overwhelm one's rational convictions (Becker, 1998). He emphasizes, two aspects of integrity. First, it requires acting in accordance with rational values, second, accordance not with any value system but with a morally justifiable (Becker, 1998).

Counselors with integrity that they are recognized as an honest person and strong character. After considering the definition which provided by some people who expert in defining integrity, author could concluding that the integrity is a concept related to consistency in actions, values, methods, measures, principles, expectations and the resulting things. The fact shows that a system, method, technique, or scientific competence is powerless as long as it is not done by a counselor who has personal qualities and integrity. Therefore, the counselor must have integrity in carrying out his profession.

Thus, in developing personal of counselors with integrity in professional ethical commitments, it should consider. First, character who personally directed to achieve quality of human being and religiousity which suits with Islamic Sharia, to fix personal life where to find and feel the meaning of life in everyday life, whose thought consist with useful knowledge, his heart filled with faith, Islam, and charity, attitudes and behavior that realization of Islamic values associated with good counseling and solid, his temperament is commendable, and counselees could produce faith, independence, high morale, peace, and love, remind to uphold a code of ethics in counseling.

As said that professional Islamic counselor should concern the following three areas to be an effective person and make a difference in career or performance (Al-Rabae, 2009); 1) Counseling philosophy, based on a world-view of counseling that makes the counselor unique from others in action and performance, 2) Moral values in human life, awareness of Islamic values related to the counseling philosophy that expresses as the difference of the views of Islamic counselors from the role of "helper", 3) Code of ethics counseling, the code of ethics conforms to the counseling philosophy and is supported by the moral values of the counselee to be effectively realized. In order to make an islamic counseling, in addition sufistic guidance 
and counseling effectively the counselor should possesed four qualifications, 1) religion qualification, 2) education qualification, 3) knowledge qualification, and 4) behavior qualification (Sutoyo, 2017).

Secondly, there are many efforts that can be made to make the counselor integrity in professional ethical commitment, from the formal path through workshop activities, seminars, or other scientific activities or informally through other publications. This activity can improve knowledge and skills as well as improve professional counselor's attitude.

The following table shows what a islamic counselor should possessed in order to become a islamic counselor with personal qualities and integrity.

\begin{tabular}{|c|c|c|}
\hline No & Aspects & The points \\
\hline 1 & Effective Self-qualities & $\begin{array}{l}\text { Faithful, loving people, good listener, empathy, } \\
\text { tolerance, flexible, honest, consistent, responsible, } \\
\text { respect, objective } \\
\text { And professional. }\end{array}$ \\
\hline 2 & Professional Ethics & $\begin{array}{l}\text { Autonomy, non-malfeasance, beneficence, justice, and } \\
\text { fidelity. }\end{array}$ \\
\hline 3 & Personal Integrity & $\begin{array}{l}\text { Consistency in actions, values, methods, measures, } \\
\text { principles, expectations and the resulting things. }\end{array}$ \\
\hline
\end{tabular}

Table 1. Qualities and integity of Islamic counselor

\section{CONCLUSION}

Firstly, Islamic counselors must have an effective personal quality in terms of Islamic Sharia and moral counseling and then can be a good example for the counselee. Secondly, the personal integrity of the counselor who has an awareness of professional commitment has the ability to explain and manage personal and professional strengths and limitations. Thirdly, building counselors with integrity in professional ethical commitments counseling should consider, character who is personally a counselor should be directed oriented to achieve quality of human being and religious spiritual suit Islamic Sharia, fixing personal life who is able to find and feel the meaning of life in everyday life, thought is filled with useful knowledge, heart filled with faith, Islam, and charity, attitudes and behaviors are realizations of Islamic values associated with good counseling and solid, his temperament is commendable, and counselees could produce faith, independence, high morale, peace, and love, reminding to uphold a code of ethics in counseling. Second, the formal path through workshop activities, seminars, or other scientific activities or informally through publication on the mass media of television, radio, newspapers, magazines, and other publications.

\section{REFERENCES}

Abdullah, S. (2009). Islamic Counselling and Psychotherapy Trends in Theory Development. Retrieved March, 10, 2012.

ABKIN. (2007). Penataan Pendidikan Profesional Konselor dan Layanan Bimbingan dan Konseling dalam Jalur Pendidikan Formal. Jakarta: Depatemen Pendidikan Nasional.

Al-Rabae, A. (2009). Muslim Counselors and the Western Code Of Ethics. دراسات نفسية وتربوية $56-1,(1) 2$.

Becker, T. E. (1998). Integrity in organizations: Beyond honesty and conscientiousness. Academy of Management Review, 23(1), 154-161.

Gladding, S. T. (2012). Konseling Profesi yang Menyeluruh. Jakarta: Indeks. 
Graham, J. R., Bradshaw, C., \& Trew, J. L. (2009). Addressing cultural barriers with Muslim clients: An agency perspective. Administration in Social Work, 33(4), 387-406.

Hanin Hamjah, S., \& Mat Akhir, N. S. (2014). Islamic Approach in Counseling. Journal of Religion and Health, 53(1), 279-289. https://doi.org/10.1007/s10943-013-9703-4

Hidayah, M. R. N., Elia, E. F. Z., Boli, F. B., \& Hambali, L. I. (2017). Komitmen pada Kode Etik Profesional. Jakarta: Kementrian Pendidikan dan Kebudayaan Direktorat Jendral Guru dan Tenaga Kependidikan.

Inayat, Q. (2001). The relationship between integrative and Islamic counselling. Counselling Psychology Quarterly, 14(4), 381-386. https://doi.org/10.1080/09515070110101478

Ishak, N. M., Amat, S., \& Bakar, A. Y. A. (2012). Counseling professional ethics from viewpoint of counselor educators.

Kushendar, K., \& Maba, A. P. (2017). Bahaya Label Negatif Terhadap Pembentukan Konsep Diri Anak Dengan Gangguan Belajar. Nidhomul Haq: Jurnal Manajemen Pendidikan Islam, 2(3), 95-102.

McFall, L. (1987). Integrity. Ethics, 98(1), 5-20. https://doi.org/10.1086/292912

Mudlor, A. (1993). Etika Dalam Islam. Surabaya: Al Ikhlas.

Munir, S. (2010). Bimbingan dan Konseling Islam. Jakarta: Kreasindo Media Cita.

Rismawaty. (2008). Kepribadian dan Etika Profesi. Yogyakarta: Graha Ilmu.

Sutoyo, A. (2013). Bimbingan dan Konseling Islam (Teori dan Praktik). Yogyakarta: Pustaka Pelajar.

Sutoyo, A. (2017). Model Bimbingan dan Konseling Sufistik untuk Mengembangkan Pribadi Yang 'Alim dan Saleh. Konseling Religi : Jurnal Bimbingan Konseling Islam, 8(33).

Wilis, S. S. (2007). Konseling Individual Teori dan Praktek. Bandung: Alfabeta.

Wiyono, B. D. (2003). Ekspektasi Kinerja Konselor.

Zayed, T. M. (2017). Conceptual and Practical Understanding of Counseling in Islam. MOJC: Malaysia Online Journal of Counseling, 2(1). Retrieved from https://ejournal.um.edu.my/index.php/MOJC/article/view/5560 